Reba Patrycja. Bioelectrical impedance in the assessment of nutritional status. Journal of Education, Health and Sport. 2020;10(5):63-68. eISSN 2391-8306. DOI http://dx.doi.org/10.12775/JEHS.2020.10.05.005

https://apcz.umk.pl/czasopisma/index.php/JEHS/article/view/JEHS.2020.10.05.005

https://zenodo.org/record/3818977

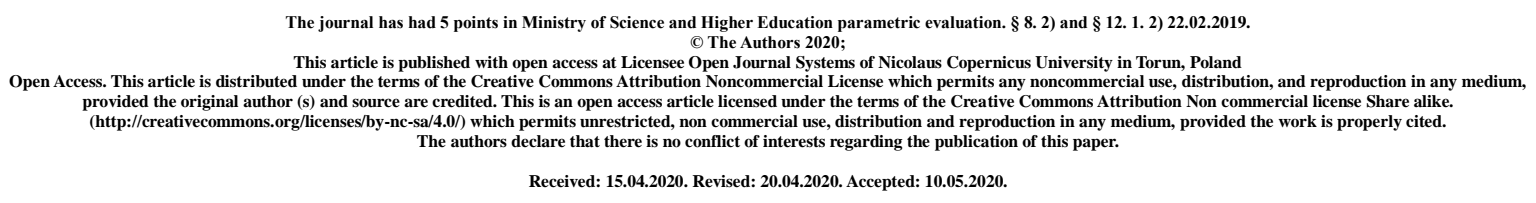

\title{
Bioelectrical impedance in the assessment of nutritional status
}

\author{
Patrycja Ręba \\ Faculty of Medicine and Health Sciences, \\ Jan Kochanowski University in Kielce
}

\begin{abstract}
Introduction

Bioelectrical impedance analysis is based on the difference in electric conduction in the water and fat environment. Adipose tissue and extracellular water are devoid of capacitive resistance (reactance), whereas they show passive electrical resistance (resistance). The current frequencies used in the bioelectrical impedance test do not affect nerve or heart muscle irritation. The current is completely safe and practically imperceptible to the patient.
\end{abstract}

Aim

The purpose of the work is to analyze bioelectrical impedance in assessing nutritional status.

Material and method

Review of available literature on the subject.

Results

Impedance is a category of electrical resistance consisting of two elements: resistance (passive electrical resistance) and reactance (capacitive, active electrical resistance). Resistance refers to the specific resistance of individual tissues. It is proportional to the voltage and inversely proportional to the total water content in the body. Reactance is associated with the electrical capacity of cell membranes that act as capacitors.

The phase angle is a parameter that illustrates the circulation of water between the intracellular and extracellular space. Provides information on cell membrane integrity, cell health and total body mobility. 
BCM changes are typical for some chronic diseases, such as AIDS or cancer.

Subjective global nutrition assessment (SGA) is the gold standard for determining nutritional status.

Conclusions

The phase angle value allows you to track the nutrition of the body as well as monitor recovery and physical fitness. Keeping $\mathrm{BCM}$ at the right level has a positive effect on your health. Maintaining BCM is a major goal in all types of nutrition therapies. FFMI allows observation of the effects of treatment, disease or aging patients.

Key words: impedance; nutritional status.

\section{Introduction}

Bioelectrical impedance is the general resistance of a biological conductor in alternating current circuits [1]. Impedance is a category of electrical resistance consisting of two elements: resistance (passive electrical resistance) and reactance (capacitive, active electrical resistance). Resistance refers to the specific resistance of individual tissues. It is proportional to voltage and inversely proportional what the total water content in the body. Reactance is associated with the electrical capacity of cell membranes that act as capacitors. Reactance implies a phase shift of current versus voltage and accounts for about $10 \%$ of the impedance value [2].

Bioelectrical impedance analysis is based on the difference in electric conduction in the water and fat environment. Adipose tissue and extracellular water are devoid of capacitive resistance (reactance), whereas they show passive electrical resistance (resistance). Current frequencies used in the bioelectrical impedance test, they do not affect nerve or heart muscle irritation. The current is completely safe and practically imperceptible to the patient. Low frequencies are associated with the flow of current through extracellular fluids and the inability to cross the cell membrane boundary, which is an insulator. Higher frequencies exert flow through external fluids and intracellular, and make the cell membrane behave like an excellent capacitor. To sum up, passive resistance is associated with extracellular fluid and intracellular, while active resistance is determined by the electrical capacity of cell membranes. Frequency is most often used in cameras $50 \mathrm{kHz}$. In such conditions, the current flows through both the outside and outside fluid and intracellular $[3,2]$.

\section{The use of selected parameters of bioelectrical impedance analysis in nutritional assessment.}

\section{Phase angle $(\mathrm{pH})$}

The phase angle is a function of resistance $(\mathrm{R})$ and reactance $(\mathrm{Xc})$ measured by bioelectrical impedance analysis. This is a measure of the phase shift of the alternating current caused by the "delay" resulting from consolidated resistance with the electrical capacity of cell membranes. It adopts the following formula:

$$
\varphi=\operatorname{arc} \text { tangent } \mathrm{Xc} / \mathrm{R}
$$

where: Xc - reactance,

$\mathrm{R}$ - resistance

and values in the range $-90^{\circ}$ to $0^{\circ}$ [2]. 
This indicator is directly proportional to body cell mass (BCM), and its higher value corresponds to better cell function. This parameter is most diagnostically relevant at a frequency of $50 \mathrm{kHz}$. Although the biological significance of the phase angle is not fully understood, it is systematically used to determine nutritional status. Provides information on cell membrane integrity, cell health and total body mobility. The phase angle value allows you to track the nutrition of the body as well as monitor recovery and physical fitness $[2,4]$.

The phase angle is a parameter that illustrates the circulation of water between the intracellular and extracellular space. I am associated with a low ratio of extracellular to intracellular water [2]. In the group of patients with heart failure, lower phase angle values are associated with the higher NYHA functional class [6] and in clinical conditions indicate poor prognosis among patients with additional concomitant anemia, volume overload [5] or thyroid disease $[2,7,8]$.

\section{Body Cell Mass (BCM)}

The body cell mass is part of the lean body mass. Indicates all cells involved in metabolic processes that determine the basic metabolic rate. BCM consists of skeletal muscle cells, smooth muscles, myocardium, internal organs, digestive system, blood, glands and the nervous system. The individual $\mathrm{BCM}$ value is determined by genetic factors, age and physical condition. The BCM content in lean body mass should be about $53-59 \%$ for men and $50-56 \%$ for women [3].

$\mathrm{BCM}$ is also a model indicator of energy consumption assessment, determining the body's need for calories. BCM measurement is crucial for analyzing nutritional status and assessing the level of patient malnutrition. Keeping BCM at the right level has a positive effect on your health. Maintaining BCM is a major goal in all types of nutrition therapies [3].

$\mathrm{BCM}$ changes are typical for some chronic diseases, such as AIDS or cancer [9].

\section{Extracellular mass / body cell mass (ECM / BCM) indicator}

The ECM / BCM indicator is a leading parameter in the assessment of nutritional status. Its value in a healthy population is below 1 due to the fact that the body cell mass is clearly greater than the extracellular mass. One of the first symptoms of malnutrition is an increase in this parameter, caused by BCM catabolism, ECM water deposition due to hyperinsulinism or water storage in the ECM for other reasons $[3,10]$.

\section{Lean Body Mass Index (FFMI)}

The lean body mass index is calculated according to the formula:

$\mathrm{FFMI}=\mathrm{FFM} /(\text { increase })^{2}$

where: FFM - lean mass.

Values lower than or equal to $15 \mathrm{~kg} / \mathrm{m}^{2}$ for women and $16 \mathrm{~kg} / \mathrm{m}^{2}$ for men indicate for lean mass deficiency [11].

FFMI allows observation of the effects of treatment, disease or aging patients. It allows to assess whether the low level of FFM achieved with age is the result of a lower height in elderly patients or changes in body structures. This indicator registers patients with excess muscle mass [12].

\section{Impedance indicator measured at 5 and $200 \mathrm{kHz}(\mathrm{Z} 5 / 200)$}

The impedance indicator $\mathrm{Z} 5 / 200$ is a parameter that determines the distribution of water. 
In severe diseases, the differences between impedance measured at $5 \mathrm{kHz}$ and $200 \mathrm{kHz}$ are similar, indicating impaired cell function. NYHA group III - IV patients achieved higher Z $5 / 200$ values compared to patients in NYHA group I - II. It should be assumed that this indicator defines a greater degree of heart failure, to whichcompanions elevated cytokine levels and reduced production of correlative anabolic factors

with increased morbidity and mortality [13].

Assessment of nutritional status using a subjective global assessment of the state nutrition (SGA)

Subjective global nutrition assessment (SGA) is the gold standard for determining nutritional status. Usesshe was interviewed about: changes in body weight, number of meals consumed, physical fitness, gastrointestinal symptoms affecting nutritional status. It is also based on a physical examination capturing the loss of subcutaneous fat, muscle tissue and swelling of the ankle or lower limb. Subjective global assessment of nutritional status is a quick, effective and reliable tool for estimating nutritional status [3].

Based on these characteristics of the interview and physical examination, the SGA is determined, which indicates the patient's nutritional status. The categories of this rating are as follows:
(A) well fed
(B) suspected malnutrition or moderate malnutrition and
(C) high risk of malnutrition or cachexia [3]. 
Tab. 1. Subjective global assessment of nutritional status (SGA) [3]

\begin{tabular}{|c|c|}
\hline AND & Interview \\
\hline Weight change & $\begin{array}{l}\text { Weight loss in the last } 6 \text { months } \\
\ldots \ldots \ldots \ldots . . .(\mathrm{kg}) \ldots \ldots \ldots(\%) \\
\text { Weight change in the last } 2 \text { weeks: } \\
\square \text { increase } \square \text { no change } \square \text { decrease }\end{array}$ \\
\hline Changes in food intake & $\begin{array}{l}\square \text { no change } \\
\square \text { changes: duration ............ (weeks) } \\
\text { Type of diet: } \\
\square \text { optimal diet based on foods } \\
\text { permanent } \\
\square \text { complete liquid diet } \\
\square \text { liquid hypocaloric diet } \\
\square \text { starvation }\end{array}$ \\
\hline $\begin{array}{l}\text { Gastrointestinal symptoms (lasting } \\
\text { more than } 2 \text { weeks) }\end{array}$ & $\begin{array}{l}\square \text { no symptoms } \square \text { nausea } \square \text { wymioty } \square \\
\square \text { diarrhea } \square \text { anorexia }\end{array}$ \\
\hline Physical capacity & $\begin{array}{l}\square \text { no change } \\
\square \text { changes: duration ....... (weeks) } \\
\square \text { type: limited work } \\
\square \text { it comes } \\
\square \text { is }\end{array}$ \\
\hline Illness and nutrient requirements & $\begin{array}{l}\text { increase in metabolic demand due to disease: none; small; average; } \\
\text { big }\end{array}$ \\
\hline II & Physical examination \\
\hline $\begin{array}{l}\text { Loss of subcutaneous fat over the } \\
\text { triceps and on the chest }\end{array}$ & 0 - unchanged, 1 - light, 2 - medium, 3 - heavy \\
\hline $\begin{array}{l}\text { Muscle atrophy (quadriceps, } \\
\text { deltoid) }\end{array}$ & 0 - unchanged, 1 - light, 2 - medium, 3 - heavy \\
\hline Swelling above the sacrum & 0 - unchanged, 1 - light, 2 - medium, 3 - heavy \\
\hline Ankle swelling & 0 - unchanged, 1 - light, 2 - medium, 3 - heavy \\
\hline ascites & 0 - unchanged, 1 - light, 2 - medium, 3 - heavy \\
\hline III & Subjective global nutrition assessment (SGA) \\
\hline & $\begin{array}{l}\square \text { correct nutritional status } \\
\square \text { suspected malnutrition or malnutrition } \\
\text { medium grade } \\
\square \text { cachexia } \\
\square \text { high risk of malnutrition }\end{array}$ \\
\hline
\end{tabular}




\section{Literature:}

1. Jaroszyk F. Biophysicist. Student handbook. PZWL Medical Publisher, Warsaw 2006.

2. Lewitt A., Mądro E., Krupienicz A. Theoretical foundations of impedance application bioelectrical. Endocrinol. Obesity. 2007, 3 (4): 79 - 84.

3. Małecka-Massalska T. Evaluation of selected parameters of impedance analysis bioelectric in patients with head and neck cancer. Publishing house Medical University of Lublin, Lublin 2012: 23 - 92.

4. Selberg O., Selberg D. Norms and correlates of bioimpedance phase angle in healthy human subjects, hospitalized patients, and patients with liver cirrhosis. Eur. J. Appl. Physiol. 2002, 86: 509-516.

5. Colin-Ramirez E., Castillo-Martinem L., Orea-Tejeda A., Asensio E., Torres F., RebollarGonzalez V., Narvaez-David R., Dorantes-Garcia J. Body composition and echocardiographic abnormalities associated to anemia and volume overload in heart failure patients. Clin. Nutr. 2006, 25: 746 - 57.

6. Castillo-Martinez L., Colin-Ramirez E., Orea-Tejeda A., Asensio E., Bernal-Rosales LP, Rebollar-Gonzalez V., Narvaez-David R., Dorantes-Garcia J. Bioelectrical impedance and strength measurements in patients with heart failure: comparison with functional class. Nutrition 2007, 23: 412 - 8.

7. Silva-Tinoco R., Castillo-Martinez L., Orea-Tejeda A., Orozco-Gutierrez JJ, Vazquez-Diaz O., Montano-Hernandez P., Flores-Rebollar A., Reza - Albarran A. Developing thyroid disorders is associated with poor prognosis factors in patient with stable chronic heart failure. Int. J. Cardiol. 2011, 147: e24 - 5.

8. Brenta G., Thierer J., Sutton M., Acosta A., Vainstein N., Brites F., Boero L., Gomez-Rosso L., Anker S. Low plasma triiodothyronine levels in heart failure are associated with a reduced anabolic state and membrane damage. Eur. J. Endocrinol. 2011, 164: 937-42.

9. Kyle UG, Bosaeus I., De Lorenzo AD, Deurenberg P., Elia M., Gomez JM, LilienthalHeitmann B., Kent-Smith L., Melchior JC, Pilich M., Scharfetter H., Schols AM, Pichard C. Composition of the ESPEN Working Group. Bioelectrical Impedance analysis - part I: review of principles and methods, Clinical Nutrition 2004 Oct; 23 (5): 1226-43.

10. Barbosa-Silva MC, Barros AJ, Post CL, Waitzberg DL, Hevmsfield SB. Can bioelectrical impedance analysis identify malnutrition in preoperative nutrition assessment? Nutrition 2003, 19: 422 - 426.

11. VanItallie TB, Yang MU, Heymsfield SB, Funk RC, Boileau RA. Height - normalized indices of the body's fat-free mass and fat mass potentially useful indicators of nutritional status. Am. J. Clin. Nutr. 1990, 52: 953 - 959.

12. Kyle UG, Schulz Y., Dupertuis YM, Pichard C. Body composition interpretation. Contributions of the fat-free mass index and the body fat mass index. Nutrition 2003 Jul-Aug; 19 (7-8): 597 - 604.

13. Castillo-Martinem L., Colin-Ramirez E., Orea-Tejeda A., Asensio E., Bernal-Rosales LP, Rebollar-Gonzalez V., Narvaez-David R., Dorantes-Garcia J. Applied nutritional investigation. Bioelectrical impedance and strength measurements in patients with heart failure: comparison with functional class. Nutrition 2007 Oct; 23: 412-418. 